\title{
12 Dual citizenship and twofold informality
}

\author{
The interstices of state power and \\ transnational lives amongst Meskhetian \\ returnees in Georgia
}

\author{
Jvan Yazdani
}

\section{Introduction}

In this chapter, I examine 'informality' in interactions amongst state institutions, non-governmental organisations and the Meskhetian diasporic communities/ returning migrants in Georgia and Azerbaijan. In doing so, I take advantage of the ambiguity inherent in the concept (Misztal 2000: 17), applying it to different levels of analysis and, further, employing it as a label for the interpretive frames imposed by Meskhetians on immigration and citizenship regulations. In other words, I rely on the category of 'informality' when I describe my research participants' practices as 'informal', as well as when I describe their interpretation of practices and systems that negatively impact their resettlement and civic membership projects. Although I consider an assessment of intent beyond the scope of my research here, 'informal governance practices' were indeed identified within the rationale of Georgian state policies during the period in which the citizenship regimes pertinent here took shape (Rekhviashvili and Polese 2017). Furthermore, devoting attention to informal practices regarding mobility in particular is, I argue, called for given the peculiarly spatial and geographical dimension of informality (Polese et al. 2016: 16).

The specific citizenship regime developed during the post-communist transition in Georgia is characterised by some as purely civic (rather than ethnic), since the new republic granted citizenship rights to all Soviet citizens permanently residing in its territory - perhaps a side effect of the highly contested politics of national identity within Georgian society (e.g., Shevel 2009: 287). Others argue-more consonant with the material presented here-for continuity between the "ethnic hierarchical' conceptions of citizenship that underpinned Soviet-era policies on nationalities and today's 'ethnic nationalist' citizenship (e.g., Khazanov 1997: 18-45). Furthermore, the Meskhetians' peculiar position within Georgian society has resulted from the strongly felt association of Georgian national identity with Orthodox Christianity (Shurgaia 2008: 250-300), and given that the Georgian language has emerged as the main element in the formation of a national identity in what is described as a 'highly language-conscious' society (Smith et al. 1998:

DOI: $10.4324 / 9781003176763-12$ 
167-196). The Meskhetians, a Turkish-speaking, Sunni Muslim population, have, therefore, been identified as an 'internalised Orient' (Cherchi and Manning 2002: 32; Tlostanova 2012: 137).

What I observed, and hope to describe adequately here, is a grey area, where informal practices of citizenship 'from above and below' interlace with each other. I characterise the interactions and endeavours within this area as informal practices of dual citizenship, because I am primarily concerned with a typology of return migration not resulting in a thorough separation from former communities and countries of residence. My research participants' lives possess an indisputable transnational quality, exhibited perhaps most comprehensively in family formation processes and in their eccentric relation to canonical, geographically sanctioned national identities.

Their choices, and the informal practices employed to carry them out, are framed - as subsequent sections make clear-by motivations and circumstances that have roots in a present of disempowerment and a past of deportation, dispossession and a loss of civic rights, a past that looms ominously over their present. Indeed, the failures to realise projects of diasporic return and mobility are ordinary. The consequences range from moving back to the country from whence migration originated, to spending years in the host country without the rights associated with membership or being forced to give up the project of return entirely. To put it bluntly, the majority of the Meskhetian returnees I met are disillusioned, embittered and weary because of the impasse in which they have found themselves.

The question that informs this chapter is thus: Does the category of 'informality' help to understand Meskhetians' interpretation and handling of the legal and mundane arrangements (which, in turn, rely on informality) that obstruct their projects of return?

Prior to analysing more recent issues, I provide an outline of the history of the 1944 Meskhetian deportation by Soviet authorities, the ensuing exile imposed on its members and the subsequent formation of its diaspora. It would be difficult, otherwise, to appreciate the current Meskhetians' predicaments. Next, I focus on the research setting, especially the legal-institutional framework of return migration: the 'Law on Repatriation', adopted by the Georgian government in 2007 and the 2014 'Law on Georgian citizenship'. The latter was passed whilst I was in the field and represented a legal shift with potentially significant repercussions for returnees' status. Describing my research participants' narratives around these issues is meant to shed some light on how their field of action is partially structured by legal-institutional frameworks as well as by their everyday encounters with different sorts of boundaries: some unambiguously geographical, and some pertaining to the interplay of history, identity politics and group narratives.

In order to better situate their historical and political plight, I also provide an argument that subsumes their experience of deportation, exile and dispersion under the definition of postcoloniality. Finally, I elaborate upon the hypothesis of formalising their status of dual citizenship as a way to accommodate the 
repatriates' cultural and civic horizons and already extant informal practices of dual citizenship.

\section{Soviet deportation and the formation of a diaspora}

Muslim Meskhetians lived in villages along the Georgian-Turkish border until November 1944, when the Soviet army deported them en masse to Central Asia. The rationale for this operation can be traced to the Soviet collectivist policies of 'demographic engineering' (King 2008: 186), one tenet of which was the belief that 'primordial ethnos' were so durable they would survive even after the eventual demise of classes and ideologies (Slezkine 1994: 449). The Muslim population of Meskheti, a southwestern region of the Georgian Soviet Socialist Republic (today, a region in the Georgian province of Samskhe-Javakheti), were thus targeted as an undifferentiated whole. According to official figures, 92,307 persons were rounded up, forced into cattle train wagons and-after a journey which lasted more than two weeks - placed under special settlement restrictions in Central Asia. These individuals included Muslim Meskhetians (Turkishspeaking Sunni Muslims), as well as Hemshins, Batumi Kurds and Terekeme. ${ }^{1}$ Additionally, nearly 30,000 soldiers from these four nationalities, returning from the war, were, in turn, also deported (Trier and Khanzin 2007: 2), something that amongst my research participants exemplifies the blatant inequity of their collective treatment.

In the eyes of the Soviet government, this likely served as a preventive measure, since Muslim Meskhetians were seen as potential collaborators with Turkey. Their removal was, thus, meant to establish a more 'reliable' border population (Nekrich 1978: 103-105). As Hasanli (2011: 3) points out, Turkey and Russia indeed shared a historically high-friction border, known for periodic conflicts dating back centuries.

The Meskhetians' fate was, therefore, decided on the grounds of imperial claims, security concerns and collective allegations. A note by the Head of the People's Commissariat of Internal Affairs (NKVD), Lavrenti Beria, stated the following: 'A considerable part of this population, related to the residents of Turkey, was engaged in smuggling, expressed their wish to emigrate and served as a recruitment ground for spies and gangsters' (cited in Hasanly 2011: 20).

Whether or not these allegations reflected any truth, the 1944 deportation order led to the relocation, in military fashion, of the entire population irrespective of sex, age, individual responsibilities or political affiliation. During the first years of displacement and exile, thousands died (Pohl 1999: 132), with some scholars reporting mortality rates reaching 14.6\% (Pohl 2008: 207). Until 1956, the deportees lived confined in 'special settlements' — very limited zones they were not permitted to leave without official permission. After the special regime was abandoned, they were still barred from returning to their homeland. Instead, starting in 1958 and throughout the 1960s, about 25,000 deportees were permitted to move to Azerbaijan, a country they perceived as transitory towards an eventual return to Georgia (Trier and Khanzin 2007: 3). Again, in 1990, 
following ethnic strife and the targeting of their communities in Uzbekistan, more than 50,000 Meskhetians arrived in Azerbaijan as refugees (Yunusov 2007: 176). The (small) number of returnees who have settled in Georgia since 2007 (the focus of my ethnography) originate from these Meskhetian communities in Azerbaijan.

The Meskhetian diaspora can, therefore, be considered a 'victim diaspora' (Cohen 2008: 39-59), given the coercive and violent nature of its inception in 1944 and successive instances of their discrimination or overt persecution. Beginning in the early 1990s, for example, thousands of returnees were forced from Georgia again. Since 2004, thousands have been accepted as refugees by the United States from the Russian province of Krasnodar.

Their 1944 mass deportation by the Soviet government and the successive episodes of victimisation, forced mobility and discrimination form a core repository for their collective narratives, alongside their personal and familial stories and their diverse and often conflicting identities. The decisive factor for the advancement of the Meskhetian cause in Georgia would be, eventually, the country's aspiration to join the Council of Europe. Throughout the 1990s, the fact that deportation had been perpetrated by (and within the then boundaries of) the USSR was still considered reason enough to exonerate the government of any responsibility. However, when, in April 1999, Georgia became a member of the Council, the Meskhetian cause was taken up as an official obligation and commitment (Trier et al. 2011: 39; Overland 2007: 534-540).

A bumpy political path led to the adoption, in 2007, of the 'Law of Georgia on the Repatriation of Persons Forcefully Resettled from Georgia by the Former Soviet Union in the 40 s of the 20 th Century' ${ }^{2}$ From its inception, this law was met with criticism by advocacy groups and Meskhetian organisations on the grounds that it provided too limited time for the submission of applications, imposed cumbersome requirements and left too much room for interpretation by government officials; it also required legal provisions that many potential repatriates found economically insurmountable (Trier et al. 2011: 37-49). By 1 January 2010 - after a two-year application period that included two deadline extensions - a total of 5841 families (8900 individuals) had applied for repatriation to Georgia, of whom only 412 were granted 'conditional citizenship'. ${ }^{3}$ In the wake of the adoption of the 'Law on Repatriation' in 2007, a few hundred Meskhetians, mostly from Azerbaijan, settled in Samskhe-Javakheti of their own accord without following the formal procedures. Some took advantage of an exception to the principle against dual citizenship and managed to become Georgian citizens. This exception was no longer available already by late 2009, when the authorities' change of attitude towards this parallel repatriation led to incidents at the border (Trier 2011: 676677 and note 73). My research focuses on those who did not manage to obtain Georgian citizenship, neither through the 2007 'Law on Repatriation' nor through the aforementioned exception. In addition to this rather tiny group in Georgia, my research also focuses on their communities in Azerbaijan and organisations related to the Meskhetian diaspora, which played a significant, albeit contentious, role in the process of repatriation to Georgia. 


\section{Research and institutional setting}

The majority of my fieldwork took place over a one-year period in Caucasian Georgia, between 2014 and 2015. It consisted of two stays, lasting eight and four months, respectively, in the village of Nasakirali (founded by returnees in the late 1970s) and the town of Akhaltsikhe, where the majority of Meskhetians arrived after 2007. My research draws upon qualitative research methods such as semi structured interviews and participation in family and community activities (e.g., harvesting, tea plucking, seasonal work trips to Turkey, etc.) as well as through small surveys and genealogical analysis. The vast majority of the 59 individuals living in Akhaltsikhe (nine households) arrived from Azerbaijan. During the time of my fieldwork, no one had yet obtained Georgian citizenship. They had repatriated independently of the legal framework laid out by the Georgian government and, thus, had not made use of the relevant laws. Most held the official 'repatriate status', a situation they denounced as unjust in view of their history and collective memories of deportation and dispossession, and of the Georgian government's unfulfilled duty of rehabilitation. Indeed, a 2015 motion of the Parliamentary Assembly of the Council of Europe describes the repatriation programme as 'mostly focused on providing a legal repatriate status to the eligible applicants and not on facilitating the actual repatriation itself'. ${ }^{4}$ My analysis, therefore, takes into account that the explicit, public aims of governance should be investigated in combination with their (un)intended effects, brought forth through informal practices as well. As Castles (2004: 854) warns, thinking exclusively in terms of the 'success' or 'failure' of migration policies limits our capacity to deconstruct agendas and goals that might be hidden or inexplicit. What (if anything) lies beneath the regulatory framework of the laws, however, is beyond the scope of this work. However, a disenchanted attitude towards state powers is resonant with the inclinations of many Meskhetians I met and with anthropology's vocation.

Within this theoretical framework, parallel to examining informality as a way to realise rights and achieve incorporation into the country of immigration by means other than institutional paths (Berenschot and van Klinken 2018: 97; Rigo 2011; Sassen 2002: 6), I also consider it as part of local theories regarding the management of mobility by states. My primary preoccupation is, thus, informality within local interpretative narratives, which thrive in an atmosphere of expectation and distrust. As such, research participants attributed informality to the state as a way of surreptitiously 'getting things done', instrumental to conspiratorial schemes against their collective return to what they consider their homeland. Often, when return migration and full membership projects failed at the individual or family level, these narratives posited the state's intentionality and hostility. A direct consequence has been growing mistrust in institutions governing citizenship and immigration. What emerges as chiefly pertinent here is the inclination of survivors of deportation or subsequent generations to read past and present suffering as programmed, and to reject explanations that postulate accidentality (Mann 2005: 8). 
At the time of my fieldwork, the tiny community of Meskhetians in Akhaltsikhe consisted of nine households, with a total of about 60 to 70 people. Typically, each household included three, sometimes four generations: an elderly, possibly direct witness of the 1944 deportation; her/his daughter/son, with their spouse, both of working age, who provided the practical impulse to repatriation; and their teenage children and, often, grandchildren.

From the strictly normative view often expressed by the government, Meskhetians' predicament is, in essence, a form of deranged, reckless migration, since they dispensed with some of the formal requirements of the law that should have allowed their settlement and naturalisation in Georgia, thus leaving Azerbaijan 'too soon' and finding themselves in legal limbo. Needless to say, opinions of this sort have generated resentment, since most Meskhetians understand their right of return as a form of historical compensation that cannot be circumscribed solely through legalistic arguments.

To complicate things further, a new citizenship law was adopted by the Georgian government in April 2014 during my fieldwork. This law introduced a more restrictive visa regime, which abolished the pre-existent ability of foreigners to reside in the country for 360 days without requiring a residence permit. ${ }^{5}$ For my research participants, the law's effects were potentially disruptive, since most were citizens of Azerbaijan.

This sudden and largely unexpected change in the legal framework exposed the fragility of Meskhetians' presence in a country to which they claimed a moral-historical right of collective return. At this particular juncture more than ever during my fieldwork, the theme of citizenship seemed charged with emotion, and conjured imaginative new forms of membership frameworks (Shafir 1998: 23). This imaginative effort was, needless to say, fraught with fears, since the new law could potentially shift the ground under the feet of people whose citizenship and sense of home lacked a formal status in the country. Memories and collective narratives of suffering at the hands of the Soviet state were, thus, mobilised along a continuum of persecution culminating in today's legal framework for repatriation. Arguably, an internalised sense of deportability played a role in this, since the relationship between their citizenship rights and the state (Peutz and De Genova 2010: 15) was promptly structured along narratives similar to those ingrained in their group identity for decades.

My fieldwork extended to their sending communities in Azerbaijan as well. Here, the failure of the repatriation programme has generated frustration and inspired the spread of conspiratorial interpretations of the procedures adopted by the Georgian and Azerbaijani governments in handling repatriation.

From a broader perspective, the circumstances of these communities-both in Georgia and Azerbaijan - fall within the peculiarities of contemporary human mobility and the restructuring of nation-states in globalisation. Indeed, the latter has led to an increase in modes of governing borders and populaces, which favour discipline over repressive state control (Geiger 2013: 34; Zolberg 2006: 443). In this sense, Meskhetians' relationship with borders and citizenship systems suggests that the reach of the states can affect latent, informal control through 


\section{Jvan Yazdani}

forms of graduated or partial membership that withholds the rights accorded to full citizens (Ong 2006: 82; Krujit 2002: 37; Schonburgh 2007: 17). These regulatory grey areas, in this case at least, seem to be perpetuated by a variety of mechanisms - at the interstices of two or more citizenship regimes - which include the mere disregard for repatriates' conundrums as well as informal, yet seemingly institutionalised practices. It is against such a theoretical background, and the experiences of my research participants, that I advance the idea of dual citizenship as an imaginative horizon, and, possibly, a practical solution. Holding two citizenships (their country of origin's as well as Georgia's, their elective homeland) would accommodate the actual life circumstances and aspirations of those (very few) in the Meskhetian transnational diaspora who opted to repatriate.

\section{New laws and informal practices}

The total number of Muslim Meskhetians in Georgia today is thought to range from 600 to 1000 (Aydıngün et al. 2006: 13). They are a politically marginalised group, whose plight, like that of other Georgian minorities, has often been perceived through the lens of ethno-political categories and national security concerns (Sabanadze 2014: 120-132; Tournon 2007: 101, 203), to the detriment of their pleas for rehabilitation and return. Meskhetians are also part of what has become a transnational diaspora dispersed throughout the former Soviet Union, Turkey and the United States. The majority of those who live in Georgia began arriving in the late 1970s, and most have become naturalised citizens. In this chapter, however, I provide examples from a small number of Meskhetians who only recently repatriated and whose status in Georgian society remains tenuous both socially and legally. I use the term 'returnees' despite the fact that most were born after the 1944 deportation. Returnee ('repatriant') is a term used by my respondents themselves. A repatriant, according to an 'emic reading of return', is someone whose family socialisation was characterised by ethnic capital and a strong ideology of return to the homeland, regardless of their place and date of birth (Christou and King 2010: 639).

Unsurprisingly, Soviet deportation was such a foundational experience that it is ingrained in today's repatriates' ethos, and is still of importance when we consider the problems they face with contemporary institutional regimes of mobility and citizenship. Mann (2005: 8) actually argues that amongst surviving victims the idea of accidental suffering is commonly unacceptable. Thus, amongst Meskhetians in Akhaltsikhe, intentionality is projected onto occurrences that lie beyond an individual's control and fall within the scope of governments.

On one particular occasion, I witnessed a bitter argument about the high mortality rates amongst the deported, which involved the son of a deportee born in the 1950s and an acquaintance of his. The Meskhetian man contended that the high mortality rates had been caused by a specific plan implemented by the Soviet authorities. His acquaintance's opinion, instead, was consistent with the theory of 'abandonment in deportation', which attributes the deaths to an unintentional lack of coordination between the place of departure and the destination (Werth 2003: 
227). Similarly, Uehling (2004: 94-95) describes how Crimean Tatar deportees challenge the deportation accounts suggesting that the operation was carried out in a 'human' way or that, at least, there was a sincere effort to do so on the part of the Soviet leadership.

These collective narratives give testimony to Meskhetians' history of abuse by the state, deployed as interpretive frameworks on today's predicaments. They offer meaning whenever the workings of the state or other political entities resist interpretation or appear to function through 'informal' mechanisms of exclusion and control.

The majority of Meskhetians who recently resettled in Georgia originate from Azerbaijan, as outlined above. Here, Meskhetian organisations, especially Vatan, strove to assist potential repatriates with application procedures. Vatan ('Homeland') was established in 1990, with the aim of promoting the return to Meskheti (currently situated roughly within the province of Samskhe-Javakheti). Testimonies from Vatan's leaders and members of local branches of the organisation, in this sense, reflect the perception of the repatriation programme and emerging notions attempting to grapple with its ambiguities. At the heart of these narratives lie the criteria utilised by the Georgian government to vet applications, and the alleged arbitrary exclusion of Vatan's members.

This is clearly exemplified by the following excerpts from interviews with Rehman and Yusuf':

Rehman: To this day, no one who works for Vatan has obtained the status of repatriate, not even one status have they given us! This law ... this law of 2007, has only damaged us, it has been adopted in order to create obstacles for our return to Georgia. ... Look at this guy, to his mother and his father they haven't given it, neither to this brother and sister, in his family they only gave it to him. What is he supposed to do? To those who work for the fatherland, they don't give the status; they give it to those who don't really care!

Another member of Vatan went even further:

Yusuf: When I speak about a filter, I mean this, for example: they learn that someone's dead, and then they send him the status!

In order to analyse these narratives, it is useful to consider the relationship between the modern state's securitarian preoccupations and its technologies of population control. Ultimately, the system of repatriation elicits political and ideological support in the public arena, but also emotional responses amongst subjects by evoking the promise of a status, the acquisition of which presupposes a wilful commitment. Thus, a space of programmed informality is generated and sustained by means of informal practices and unspoken rules of behaviour. Within this civic limbo, full membership in society is suspended - that is, postponed until the formal criteria are met (chiefly, having renounced one's original citizenship). 
Still, informal fields of action seem equally important, since they pertain to domains that escape planning, control and, sometimes, cognition.

Informality should, thus, be understood here as the modality of behaviour adopted by a range of actors, from individuals to state and community institutions. A space is constituted in which citizenship can be conceptualised not only as a practice but also as an interpretive framework. The examples above reflect the application of such framework to bureaucratic and legal procedures which are enigmatic or raises legitimate doubts. We can argue that the condition the repatriates enter represents one in which the friction between their status of incomplete citizenship and partial, informal incorporation into society takes place within the law itself, rather than outside it (Chauvin and Garcés-Mascarenas 2012: 243). What this perspective allows us to see, I believe, is also the ongoing relevance of the nation-state as the source of citizenship rights in this era of globalisation (Tölölyan 1991: 5; Oommen 2006: 34). This is a crucial point since the field of informal practices I consider is not beyond the reach of - or necessarily in defiance of - the state(s) across whose boundaries the Meskhetians move and live their lives.

The work of state institutions, therefore, also depends upon informal instruments: in order to vet repatriation applications, the Georgian government instituted a Council of Elders ${ }^{7}$, composed of senior members of the Meskhetian community. This council's work relies on ethnic and kinship networks, and its legitimacy is based on the respect elicited by its members amongst Meskhetians. In the words of Nino, a Georgian nongovernmental worker:

The Council of Elders ... an institution which was created ... to make sure that the individuals are identified, those who cannot demonstrate they were deported. Basically, there were cases of individuals who claimed to have been deported, but neither them nor their ancestors had been.

But what kind of documents can they provide?

When these people were deported, they were given papers which stated when and from where they were deported, a tiny piece of paper with their name and date ...

A document 70 years old is difficult to come by ...

It's true. ... Since the main criterion for repatriation is that the person, or his ancestors, were deported, and many could not prove it with a document, the government had to verify that they really were deported, or their ancestors were. That's why they created this Council of Elders, which is an organism comprising three elders who verify the requirements of each person. The Ministry sends them the documents when everything else is verified and they ask them to make sure these people are truly deportees. They have personal networks, personal connections with the deported communities in Azerbaijan and elsewhere; it's enough to make a call, be in touch with these communities, they have personal contacts, they know someone, and so on.... Thanks to this process the government managed to give more than 1000 individuals a status. Otherwise the applications meeting the prerequisites would be 75 ... They 
are leaders within their communities, respected by other Meskhetians, and for this reason they were chosen. ... They have contacts, know many people.

If the defining element of 'informal citizenship' is the role of personal connections in dealing with state institutions (Berenschot and van Klinken 2018: 99), the institution of the Council of Elders reflects the very embodiment of this principle. Informality compensates, in this case, for the lack of proper documentation, and, as clearly explained in the interview excerpt above, made it possible for a much larger number of people to access the application procedure. Nonetheless, it is also a source of conjecture and distrust, often directed at the very members of the Council, who are sometimes negatively associated with the Georgian government and accused of personally benefiting from their role.

\section{Postcoloniality: nationality, naturalisation and transnational horizons}

The question of whether the experiences of Meskhetian deportation, exile and dispersion, as well as their current relationship with their homeland, could be subsumed under the definition of postcoloniality is tied to the wider debate on whether the post-Soviet space itself should be included in postcolonial studies. Although the second question lies beyond our scope here, a number of elements speak in favour of answering the first question affirmatively, at the very least from the point of view of the Meskhetians' experiences. For one thing, mass and arbitrary relocations of entire collectives and Soviet nationality policies and practices qualify as postcoloniality (Chioni Moore 2001: 123). Given the defining character of deportation for Meskhetians' collective identity, the category of postcoloniality seems appropriate. Possessing an equally colonial tint are those 'cultural technologies of rule' (Hirsch 2005: 307), such as the census and passport systems, integral to the project and implementation of collective relocation, as a colonial means of constituting subject positions through representation (Slemon 2003: 46). Seen in the analytical context of a postcolonial relationship, the status of the Meskehtians who recently migrated to Georgia could be explained as a form of a disaggregated right containing partial recognition and elements of nationality (Cohen 2014: 147-148). The spectre looming in Meskhetians' imagination may represent the 'infinite danger' of statelessness (Walzer 1983: 32), a condition in the postcolonial perspective that must refer to migration as much as to the 'game of citizenship' (Samaddar 2020). To complete this picture, the Arendtian reflection of statelessness highlights avoiding the dilemma of the irrational, stateless nonperson, such that statelessness is avoided from the perspective of the state as well, conferring partial bundles of rights as a means of expressing a difference in an institutional capacity whilst maintaining its control over the population (Cohen 2014: 132-134). The Meskhetian repatriates, particularly those left in legal limbo through the shortcomings of the repatriation programme, appear trapped in a postcolonial space that lacks a proper centre-periphery structure: their direction is not towards their former metropolitan state, but a new one that has only reluctantly 
taken on the task of repatriation. Moreover, the very proliferation of international boundaries resulting from the birth of post-Soviet republics complicates, at least symbolically, their return (Martin 2001: 333), leaving a bittersweet taste to their appraisal of the dissolution of the Soviet Union and the post-Soviet transitions to democracy.

It comes as no surprise then, given the (at least perceived) threat of statelessness and the possibility of ushering in a liminal state, that giving up their Azerbaijani citizenship (an official requirement to naturalise as Georgian) becomes a nonviable, seemingly irrational option.

The arbitrariness of informal bureaucratic practices manifests in the uncertainty surrounding the very amount of money to be paid to the Azerbaijani authorities in order to give up one's citizenship (ranging 'from USD 250 to $170^{\prime 8}$ ). In addition, other uncertainties surround one's rights including, for instance, the inability to inherit and possess property in the country of origin - an unreasonable prospect for people whose lives have become practically transnational. All these factors contribute to the failure of most to naturalise, a problem that could potentially be addressed by allowing for dual nationality (Hammar 1985: 442). This would represent a gesture of practical as well as symbolic compensation for people who have been historically disempowered and victimised through policies around nationality.

One conclusion I draw, then, is that informality should be seen as an idiom and a code of conduct not necessarily relegated to the margins of state practices, but rather implicated as a part of the very rationale for state power. Navigating around the obstacles it poses involves a capacity to act along a transnational horizon of mobility and lifestyles. Several Meskhetian men, for example, engage in seasonal work in Turkey, new families frequently create a bridge originating from a Meskhetian community abroad, remittances are sent from kin abroad and participation in the informal economy is also common through, for example, the sale of products from small plots of land or dairy products. These and a myriad of other practices that exceed the formal expectations of national communities coexist within groups that continue representing themselves as culturally bounded and self-sustaining. Yet, these practices are pragmatically enmeshed in relationships of economic and political interdependency necessary for reshaping notions of citizenship (Thunder 2014: 79-80). In this sense, the pursuit of naturalised citizenship is but one facet of a more complex strategy, wide-reaching in a literal, geographical sense and involving unique understandings of transnational contexts (Gutiérrez 2008: 196). What the subjects substantiate here is a procedural, civic idea of citizenship, rather than a holistic, romantic, cultural one (Rapport 2005: 205), which subjectively dilutes the nationalist, formal core of conventional citizenship (Zolberg 2000: 517). Where repatriates' and state practices interact, overlap and enter into conflict, informality plays out publicly in the 'game of citizenship'. Still, it retains its shadowy qualities as a cognitive lens through which hegemonic manifestations of regulatory powers are interpreted.

A shrewd look at these migratory policies might blur the boundaries between 'success' and 'failure', or 'formal' and 'informal' practices, attributing informality 
to a grey area wherein citizenship is negotiated. Such a relativisation of citizenship entails a circumspect assessment of the naturalisation path afforded by the 'Law on Repatriation'. The perceived trade-off they are offered, between renouncing their citizenship of origin and the promise of a new one, becomes disempowering for people living a de facto transnational life (Iordachi 2004: 135). In a sense, the moral and spiritual implications, as well as the practical impact, of the "national order of things' (Malkki 1992: 26) are at odds with aspirations that still retain an echo of the Soviet cosmopolitanism of ordinary life (Humphrey 2004: 151), albeit embodied in its Caucasian variant as a continually 'deferred project' (Grant 2010: 124). Personal and collective memories of violence and dispossession instilled a sense of vulnerability within the Meskhetian diaspora's sense of self, possibly explaining their unwillingness to accommodate return and mobility projects. Thus, naturalisation is impossible lest one severs citizenship ties with their nationality of origin.

Dual citizenship, however, would recognise the inscription of the repatriates' existence within a transnational order, granting it legitimacy. As Spiro (2010: 127) points out, a regime that suppresses plural citizenship incentivises individuals to select the one with the greatest personal salience, based on a number of practical as well as symbolic and emotional factors. Such choice seems to represent an insurmountable obstacle to realising the repatriates' rights. Mobilising this concept functions, in my opinion, as more than a mere speculative exercise. Repatriates' informal practices of citizenship are, in fact, informal practices of dual citizenship. It is in this direction that reluctance to strip themselves of their nationality of origin, rather than mere economic considerations, becomes intelligible. Naturalised citizenship in both countries would, thus, recognise their transnational lives (Kivisto and Faith 2015: 139), and perhaps achieve a form of historical compensation.

\section{Conclusions}

This chapter reflected on the informal practices of (dual) citizenship (Sassen 2002: 6) amongst disenfranchised individuals. At the same time, it utilised the category of informality vis-à-vis local interpretations of legal frameworks, notably of the (un)intended effects — or implicit aims — of norms regulating mobility and membership in the national polity (which, in turn, often rely on informal practices of exclusion). Informality has, thus, been understood as a principle of action, thought and perhaps governance, used to describe the actions of disempowered, marginal individuals and communities as well as policies. On the first level, it works as a way of 'getting things done', of gaining something by compensating for the restraints imparted by laws and regulations, by one's status in society, such as what I have described in this chapter as 'informal practices of dual citizenship'. For the Meskhetian repatriates in Georgia, this means cultivating a fractured sense of home, bifocal at least and perpetually incomplete.

In this chapter, I investigated Meskhetians' perceptions of state powers in redefining the boundaries of the legal (echoing historical experiences of the 


\section{Jvan Yazdani}

betrayal of established norms of citizenship (Levin 2017: 4)) drawing from the impact of the 2014 'Law on Citizenship'. On the second level, informality serves as a means of achieving particular goals through ambiguous forms of governance that generate grey areas. Meskhetians' informal citizenship practices, therefore, arise through a dialogue with the informality of the institutional and legal framework of the repatriation programme. Undoubtedly, this represents an unequal relationship, within which their life projects and the accomplishments of everyday work appear open to revision and possibly stripped from them at any time. It is a state of things in which people perceive - and are affected bystructures of inequality inscribed in their imperfect membership status, rendering them vulnerable to social and embodied forms of suffering. The question of purpose is relevant here, chiefly as part and parcel of local interpretative frameworks, arising from histories of victimisation and a quest for reparation. In this light, the principle of informality qualifies one dimension through which the returnees experience the state(s): time and money-wasting bureaucratic hurdles, loopholes in the legal framework and so on. These everyday complications force one to conduct their lives in grey areas and through informal practices of citizenship. The idea of 'dual citizenship' is, therefore, advanced again in this chapter. But here it represents a formal embrace of the contradictions of the returnees' transnational lives. Through dual citizenship, multiple memberships and histories would be brought to light and legitimised. The informal principle could, thus, offer analytical tools via which to address immigration and citizenship law, primarily - as we have seen - by bringing local interpretative models into our analysis. Furthermore, looking through the lens of 'informality' sheds light on certain modes of governance, especially in the fields of migration and citizenship, which generate uncertainty and vulnerability.

\section{Notes}

1 A shared history of deportation, resettlement and exile has blurred the boundaries of the groups within the deported population.

2 https://matsne.gov.ge/ru/document/download/22558/6/en/pdf.

$3 \mathrm{http}: / /$ assembly.coe.int/nw/xml/XRef/Xref-XML2HTML-en.asp?fileid=21750\&lang $=$ en.

$4 \mathrm{http} / / /$ assembly.coe.int/nw/xml/XRef/Xref-XML2HTML-en.asp?fileid=21750\&lang $=$ en.

5 https://www.gov.uk/government/news/georgia-new-visa-regulations; http://www.refw orld.org/docid/53835fe14.html.

6 I use fictional names to protect my interlocutors' privacy.

7 https://ge.boell.org/en/2011/11/02/repatriation-issues-muslim-meskhetians.

8 From my field notes.

\section{References}

Aydıngün, A., Harding, Ç.B., Hoover, M., Kuznetsov, I. and Swerdlow, S. (2006) Meskhetian Turks: An Introduction to their History, Culture, and Resettlement Experiences, Washington D.C.: Cultural Orientation Resource Center-Culture Profile. 
Berenschot, W. and van Klinken, G. (2018) 'Informality and Citizenship: The Everyday State in Indonesia', Citizenship Studies, 22(2), pp. 95-111, https://doi.org/10.1080/1 3621025.2018.1445494.

Catles, S. (2004) 'The Factors That Make and Unmake Migration Policies', International Migration Review, 38(3), pp. 852-884, https://doi.org/10.1111/j.1747-7379.2004.tb00 222.x.

Chauvin, S. and Garceés-Mascarenas, B. (2012) 'Beyond Informal Citizenship: The New Moral Economy of Migrant Illegality', International Political Sociology, 6, pp. 241259, https://doi.org/10.1111/j.1749-5687.2012.00162.x.

Cherchi, M. and Manning, H.O. (2002) 'Disciplines and Nations: Niko Marr vs. His Georgian Students on Tbilisi State University and the Japhetology/Caucasology Schism', Carl Beck Papers in Russian \& East European Studies, 1603.

Chioni Moore, D. (2001) 'Is the Post- in Postcolonial the Post- in Post-Soviet? Toward a Global Postcolonial Critique', PMLA, 116(1), pp. 111-128.

Christou, A. and King, R. (2010) 'Imagining 'home': Diasporic Landscapes of the GreekGerman Second Generation', Geoforum, 41, pp. 638-646, http://dx.doi.org/10.1016/j .geoforum.2010.03.001.

Cohen, E.F. (2014) Semi-Citizenship in Democratic Politics, Cambridge: University Press, https://doi.org/10.1017/CBO9780511642333.

Cohen, R. (2008) Global Diasporas. An Introduction, London: Routledge, doi:10.4324/9780203928943.

Geiger, M. (2013) 'The Transformation of Migration Politics: From Migration Control to Discplining Mobility', in Geiger, M. and Pécoud, A. (eds.) Disciplining the Transnational Mobility of People, Palgrave, pp. 15-40, doi:10.1057/9781137263070.

Grant, B. (2010) 'Cosmopolitan Baku', Ethnos, 75(2), pp. 123-147, https://doi.org/10.1 080/00141841003753222.

Gutiérrez, D.G. (2008) 'Citizenship Dispersed: A Third Space Looking for Its Proper Place', in Ciprut, J.V. (ed.) The Future of Citizenship, Cambridge, MA: MIT Press, pp. 191-227.

Hammar, T. (1985) 'Dual Citizenship and Political Integration', International Migration Review, 19(3), pp. 438-450, https://doi.org/10.1177/019791838501900303.

Hasanli, J. (2011) Stalin and the Turkish Crisis of the Cold War, 1945-1953, Lanham, MD: Lexington Books.

Hirsch, F. (2005) Empire of Nations: Ethnographic Knowledge \& the Making of the Soviet Union, Ithaca, NY: Cornell University Press.

Humphrey, C. (2004) 'Cosmopolitanism and Kosmopolitizm in the Political Life of Soviet Citizens', Focaal-European Journal of Anthropology, 44, pp. 138-152, https://doi.org $/ 10.3167 / 092012904782311245$.

Iordachi, C. (2004), 'Dual Citizenship in Post-Communist Central and Eastern Europe: Regional Integration and Inter-ethnic Tensions', in Ieda, O. and Tomohiko, U. (eds.) Reconstruction and Interaction of Slavic Eurasia and its Neighboring World, Sapporo: Slavic Research Center, Hokkaido University, pp. 105-139.

Khazanov, A.M. (1997) After the USSR: Ethnicity, Nationalism, and Politics in the Commonwealth of Independent States, Madison: University of Wisconsin Press.

King, C. (2008) The Ghost of Freedom: A History of the Caucasus, Oxford: Oxford University Press, doi:10.1093/acprof:oso/9780195177756.001.0001.

Kivisto, P. and Faist, T. (2015), Citizenship: Discourse, Theory, and Transnational Prospects, Malden, MA: Blackwell Publishing.

Kruijt, D. (2002) Informal Citizens: Poverty, Informality and Social Exclusion in Latin America, Amsterdam: Rozenberg; London: Global. 
Levin, I. (2017) 'Caught in a Bad Romance: Displaced People and the Georgian State', Citizenship Studies, 22(1), pp. 19-36, https://doi.org/10.1080/13621025.2017. 1410781.

Malkki, L. (1992) 'National Geographic: The Rooting of Peoples and the Territorialization of National Identity among Scholars and Refugees', Cultural Anthropology, 7(1), Space, Identity, and the Politics of Difference, pp. 24-44, doi:10.1525/ can.1992.7.1.02a00030.

Mann, M. (2005) The Dark Side of Democracy. Explaining Ethnic Cleansing, Cambridge: Cambridge University Press.

Martin, T. (2001), 'Stalinist Forced Relocation Policies: Patterns, Causes, Consequences', in Weiner, M. and Stanton Russell, S. (eds.) Demography and National Security, Oxford: Berghahn Books, 305-39.

Misztal, B.A. (2000) Informality: Social Theory and Contemporary Practice, London: Routledge, https://doi.org/10.1111/1467-954X.00359-5.

Nekrich, A.M. (1978) The Punished Peoples: The deportation and Fate of Soviet Minorities at the End of the Second World War, New York: W.W. Norton \& Company.

Ong, A. (2006) Neoliberalism as Exception: Mutations in Citizenship and Sovereignty, Durham: Duke University Press, https://doi.org/10.1215/9780822387879.

Oommen, T.K. (2006) 'Identity: Enabling and Endangering Citizenship', in Mohanty, R. and Tandon, R. (eds.) Participatory Citizenship: Identity, Exclusion, Inclusion, London: SAGE, pp. 29-50.

Overland, I. (2007) 'International Organisations, Regional Politics and the Meskhetian Turks', in Trier, T. and Khanzhin, A. (eds.) The Meskhetian Turks at a Crossroads: Integration, Repatriation or Resettlement? Berlin: LIT Verlag, pp. 532-556.

Peutz, N. and De Genova, N. (2010) 'Introduction', in De Genova, N. and Peutz, N. (eds.) The Deportation Regime: Sovereignty, Space and the Freedom of Movement, Durham: Duke University Press, pp. 1-29, https://doi.org/10.1215/9780822391340.

Pohl, J.O. (1999) Ethnic Cleansing in the USSR, 1937-1949, London: Greenwood.

Pohl, J.O. (2008) 'The Loss, Retention, and Reacquisition of Social Capital by Special Settlers in the USSR, 1941-1960', in Buckley, C.J. et al. (eds.) Migration, Homeland, and Belonging in Eurasia, Washington, DC: Woodrow Wilson Center Press; Baltimore, MD: Johns Hopkins University Press, pp. 203-222.

Polese, A., Rekhviashvili, L. and Morris, J. (2016) 'Informal Governance in Urban Spaces: Power, Negotiation and Resistance among Georgian Street Vendors', Geography Research Forum, 36, pp. 15-32.

Rapport, N. (2005) 'Discussion: Anthropology and Citizenship', Social Anthropology, 13(2), pp. 203-206, https://doi.org/10.1111/j.1469-8676.2005.tb00008.x.

Rekhviashvili, L. and Polese, A. (2017) 'Liberalism and Shadow Interventionism in PostRevolutionary Georgia (2003-2012)', Caucasus Survey, 5(1), pp. 27-50. doi:10.1080/ 23761199.2017.1283471, https://doi.org/10.1080/23761199.2017.1283471.

Rigo, E. (2011) 'Citizens Despite Borders: Challenges to the Territorial Order of Europe', in Squire, V. (ed.) The Contested Politics of Mobility: Border Zones and Irregularity, London: Routledge, pp. 199-215, https://doi.org/10.4324/9780203839829.

Sabanadze, N. (2014) 'Georgia's ethnic diversity: a challenge to state-building', in Jones, S.F. (ed.) The making of modern Georgia 1918-2012, London: Routledge, pp. 119-140, https://doi.org/10.4324/9781315818207.

Samaddar, R. (2020) The Postcolonial Age of Migration, London: Routledge, doi:10.4324/9780429324697. 
Sassen, S. (2002) 'The Repositioning of Citizenship: Emergent Subjects and Spaces for Politics', Berkeley Journal of Sociology, 46, pp. 4-25, doi:10.1353/ncr.2003.0028.

Schonburgh, E.D. (2007) 'Informal Economy and Informal Citizenship: Exploring Causation and Connectivity in Socio-Politico Shifts in Jamaica', Caribbean Development Review, 1, pp. 1-16.

Shafir, G. (1998) 'Introduction', in Shafir, G. (ed.) The Citizenship Debates: A Reader, Minneapolis, MN: University of Minnesota Press, pp. 1-28.

Shevel, O. (2009) 'The Politics of Citizenship Policy in New States', Comparative Politics, 41(3), pp. 273-291, https://doi.org/10.5129/001041509X12911362972197.

Shurgaia, G. (2008) ‘La Chiesa Ortodossa di Georgia ieri e oggi', in Ferrari, A. (ed.) Popoli e Chiese Dell'oriente Cristiano, Roma: Edizioni Lavoro, pp. 249-303.

Slemon, S. (2003) 'The Scramble for Post-colonialism', in Ashcroft, B. et al. (eds.) The Post-Colonial Studies Reader, London: Routledge, pp. 45-52.

Slezkine, Y. (1994) 'The USSR as a Communal Apartment, or How a Socialist State Promoted Ethnic Particularism', Slavic Review, 53(2), pp. 414-452, https://doi.org/10 $.2307 / 2501300$.

Smith, G. et al. (1998), 'Language Myths and the Discourse of Nation-Building in Georgia', in Law, V. et al. (eds.) Nation-Building in the Post-Soviet Borderlands: The Politics of National Identity, Cambridge: Cambridge University Press, pp. 167-196, doi: 10.1017/ CBO9780511598876.010.

Spiro, P.J. (2010), 'Dual Citizenship as Human Right', International Journal of Constitutional Law, 8(1), pp. 111-130, https://doi.org/10.1093/icon/mop035.

Thunder, D. (2014) Citizenship and the Pursuit of the Worthy Life, Cambridge: Cambridge University Press, https://doi.org/10.1017/CBO9781107706439.

Tlostanova, M. (2012) 'Postsocialist $\neq$ Postcolonial? On Post-Soviet Imaginary and Global Coloniality?', Journal of Postcolonial Writing, 48(2), pp. 130-142, https://doi.org/10.1 080/17449855.2012.658244.

Tölölyan, K. (1991) 'The Nation-State and Its Others: In Lieu of a Preface', Diaspora: A Journal of Transnational Studies, 1(1), pp. 3-7, 10.1353/dsp.1991.0008.

Tournon, S. (2007) "La Géorgie face au retour des Meskhètes", Le courrier des pays de l'Est, 2: 1060, pp. 99-102.

Trier, T. (2011) 'National Minorities in Georgia: An Update of Developments in 2008 and 2009', European Yearbook of Minority Issues, 8, pp. 645-680, https://doi.org/10.1163 /22116117-90001688.

Trier, T. and Khanzin, A. (2007) 'Introduction', in Trier, T. and Khanzin, A. (eds.) The Meskhetian Turks at a Crossroads: Integration, Repatriation, or Resettlement? Berlin: Lit Verlag, pp. 1-39.

Trier, T., Tarkhan-Mouravi, G. and Kilimnik, F. (2011) Meskhetians: Homeward Bound, Tbilisi: ECMI-Caucasus.

Uehling, G.L. (2004) Beyond Memory. The Crimean Tatars' Deportation and Return, New York: Palgrave Macmillan, 10.1057/9781403981271.

Walzer, M. (1983) Spheres Of Justice: A Defence of Pluralism and Equality, New York: Basic Books.

Werth, N. (2003) 'The Mechanism of a Mass Crime: The Great Terror in the Soviet Union, 1937-1938', in Gellately, R. and Kiernan, B. (eds.), The Spectre of Genocide: Mass Murder in Historical Perspective, Cambridge: Cambridge University Press, pp. 20152239, doi:10.1017/CBO9780511819674.010. 


\section{Jvan Yazdani}

Yunusov, A. (2007) 'Consolidating National Identity in Exile: The Meskhetian Turks in Azerbaijan', in Trier, T. and Khanzhin, A. (eds.) The Meskhetian Turks at a Crossroads: Integration, Repatriation or Resettlement? Berlin: LIT Verlag, pp. 172-196.

Zolberg, A.R. (2000) 'The Dawn of Cosmopolitan Denizenship', Indiana Journal of Global Legal Studies, 7(2), Article 3, pp. 511-518.

Zolberg, A.R. (2006) A Nation by Design. Immigration Policy in the Fashioning of America. Cambridge, MA; London: Harvard University. 